\title{
Gene expression profiling of human mesenchymal stem cells derived from bone marrow during expansion and osteoblast differentiation
}

\author{
Birgit Kulterer ${ }^{1}$, Gerald Friedl ${ }^{2}$, Anita Jandrositz ${ }^{3}$, Fatima Sanchez-Cabo ${ }^{1}$, \\ Andreas Prokesch ${ }^{1}$, Christine Paar ${ }^{1}$, Marcel Scheideler ${ }^{1}$, \\ Reinhard Windhager ${ }^{2}$, Karl-Heinz Preisegger ${ }^{3}$ and Zlatko Trajanoski*1
}

Address: ${ }^{1}$ Institute for Genomics and Bioinformatics and Christian-Doppler Laboratory for Genomics and Bioinformatics, Graz University of Technology, Graz, Austria, ${ }^{2}$ Department of Orthopaedics, Medical University of Graz, Graz, Austria and ${ }^{3}$ Eccocell Biotechnology Inc., Graz, Austria

Email: Birgit Kulterer - birgit.kulterer@gmx.at; Gerald Friedl - gerald.friedl@meduni-graz.at; Anita Jandrositz - jandrositz@eccocell.com; Fatima Sanchez-Cabo - f.sanchezcabo@tugraz.at; Andreas Prokesch - andreas.prokesch@tugraz.at; Christine Paar - christine.paar@tugraz.at; Marcel Scheideler - marcel.scheideler@tugraz.at; Reinhard Windhager - reinhard.windhager@meduni-graz.at; Karl-Heinz Preisegger - karlheinz.preisegger@eccocell.com; Zlatko Trajanoski* - zlatko.trajanoski@tugraz.at

* Corresponding author

Published: 12 March 2007

BMC Genomics 2007, 8:70 doi:10.1186/147/-2164-8-70

This article is available from: http://www.biomedcentral.com/I47/-2/64/8/70

(c) 2007 Kulterer et al; licensee BioMed Central Ltd.

This is an Open Access article distributed under the terms of the Creative Commons Attribution License (http://creativecommons.org/licenses/by/2.0), which permits unrestricted use, distribution, and reproduction in any medium, provided the original work is properly cited.
Received: I August 2006

Accepted: 12 March 2007

\begin{abstract}
Background: Human mesenchymal stem cells (MSC) with the capacity to differentiate into osteoblasts provide potential for the development of novel treatment strategies, such as improved healing of large bone defects. However, their low frequency in bone marrow necessitate ex vivo expansion for further clinical application. In this study we asked if MSC are developing in an aberrant or unwanted way during ex vivo long-term cultivation and if artificial cultivation conditions exert any influence on their stem cell maintenance. To address this question we first developed human oligonucleotide microarrays with 30.000 elements and then performed large-scale expression profiling of long-term expanded MSC and MSC during differentiation into osteoblasts.

Results: The results showed that MSC did not alter their osteogenic differentiation capacity, surface marker profile, and the expression profiles of MSC during expansion. Microarray analysis of MSC during osteogenic differentiation identified three candidate genes for further examination and functional analysis: ID4, CRYAB, and SORTI. Additionally, we were able to reconstruct the three developmental phases during osteoblast differentiation: proliferation, matrix maturation, and mineralization, and illustrate the activation of the SMAD signaling pathways by TGF- $\beta 2$ and BMPs.
\end{abstract}

Conclusion: With a variety of assays we could show that MSC represent a cell population which can be expanded for therapeutic applications.

\section{Background}

In recent years mesenchymal stem cells (MSC) have generated a great deal of interest as a potential source for cellbased therapeutic strategies. Human MSC are easy to iso- late from small aspirate of bone marrow via their adherence ability. These cells readily generate single-cellderived colonies that can be highly expanded and differentiated into a variety of cell types, such as osteoblasts 
$[1,2]$, adipocytes [3], myocytes [4], astrocytes and neurons $[5,6]$. Further, human MSC can improve cardiac function after infarction $[7,8]$ or symptoms of bone and cartilage defects [9-13], as well as neurodegenerative diseases such as Alzheimer's [14-16]. Their efficiency in multiple types of cellular therapeutic strategies has been demonstrated, including applications in treating children with osteogenesis imperfecta [17], hematopoietic recovery [18], and bone tissue regeneration $[19,20]$. Also first preclinical trails are in progress to test their capacity and toxicity in applications for human treatment [21].

One great advantage of MSC is that these cells may be directly obtained from individual patients, thereby eliminating the complications associated with immune rejection of allogenic tissue and infectious diseases. However, for cell therapies MSC have to be expanded and/or manipulated to obtain a sufficient amount of cells that can be subsequently used for treatment. Despite growing experience and knowledge concerning human MSC and their use in cell-based strategies, the molecular mechanisms that govern MSC self-renewal, expansion and multilineage differentiation are not well understood and remain an active area of investigation.

In this study we asked if human MSC are developing in an aberrant or unwanted way during ex vivo long-term cultivation and if cultivation conditions exert any influence on their stem cell maintenance. To address this question systematically and comprehensively we first developed human oligonucleotide microarrays with 30.000 elements and then performed large-scale expression profiling of long-term expanded MSC isolated from clinically relevant samples. We monitored these cells during their expansion ex vivo with respect to proliferation kinetics, surface marker profile and differentiation potential. Finally we analyzed the gene expression profiles of MSC during osteogenic differentiation. Our results showed that expansion of MSC does not result in substantial genetic and morphological aberrations. We illustrated for the first time in a human model the three main stages of osteogenic development, and we could show the diverse regulation of the SMAD pathways by TGF- $\beta 2$ and BMPs.

\section{Results \\ Human MSC maintain their undifferentiated phenotype during long-term expansion}

The results of the ex vivo long-term expansion experiments showed that the undifferentiated phenotype of MSCs is maintained with respect to differentiation potential, surface marker profile and gene expression profiles. At confluence of $75-85 \%$ the cultivated cells were detached and flow cytometry analysis were performed to verify the purity of the cell population without any contaminations, such as haematopoietic cells. Following surface marker profile were detected: CD44+, CD90+, CD73+, CD105+, CD166+, CD11b-, CD34-, CD45-, CD117-, HLA DR-. For the subsequent experiments MSCs were expanded until the end of the tenth passage. At the end of each passage the cells were analyzed by flow cytometry and a cell aliquot was seeded out for testing their differentiation ability.

\section{Proliferation kinetics and differentiation potential}

The growth kinetics of five donors was investigated from the primary culture through the tenth passage, corresponding to approximately 26 cell doublings. For recalculating the starting number of MSC in the MNC fraction, CFU assays were performed and the MSC frequency was determined. Primary cultures reached their first confluence from around $80 \%$ in about 2 weeks and about 10 cell doublings. During the following passages the proliferation rate slowed down. During the whole expansion period - starting with passage two until passage ten - in every passage the osteogenic differentiation ability was tested. The osteogenic differentiation was confirmed by Alizarin Red S staining and Alkaline Phosphatase assay. Throughout this examination period differentiation ability into osteoblasts was observed in low passages (passage 2, after 12 cell doublings) as well as in a higher passage (passage 10, after 26 cell doublings), (Figure 1). MSC expanded to approximately 26 cell doublings were able to differentiate into adipocytes (Figure 1).

\section{Surface marker profile}

After the cultivation of MSC from the mononuclear cell fraction (passage 0 ) and at the end of each individual passage, the MSC were analyzed by flow cytometry to monitor the surface marker profile during their ex vivo expansion. Each investigated passage depicted homogenous cell population demonstrating that MSC did not alter their physical and morphological properties during high grade ex vivo expansion under the culture conditions tested [see Additional file 1]. In addition to the examination of the surface marker profile, we also performed Realtime RT-PCR Sybr ${ }^{\mathrm{TM}}$ Green I assays for stem cell specific genes. The examined stem cell markers, CD44, CD73, CD166, CD105, CD90 and STRO1 showed stable expression level during the whole expansion period proving the results obtained by FACS analyses. As expected, CD34, CD45 and TERT could not be detected on any examined time point [see Additional file 2].

\section{Large-scale gene expression profiling of MSC during ex vivo expansion}

In order to monitor the molecular events that govern the ex vivo expansion of undifferentiated MSC we performed large-scale gene expression profiling using oligonucleotide microarrays with 29952 elements (ArrayExpress, accession numbers A-MARS-2, E-MARS-5, and E-MARS-6, [see Additional file 3, 4, 5]). After background correction, 


\section{Alizarin Red S staining}

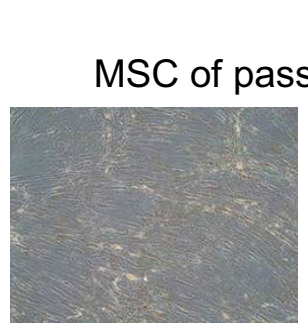

(A) Control, day 21
(B) Induced, day 21

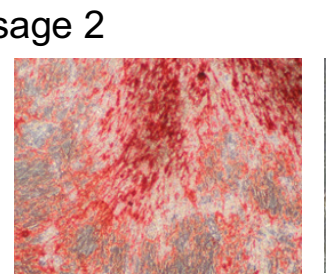

Alkaline phosphatase assay

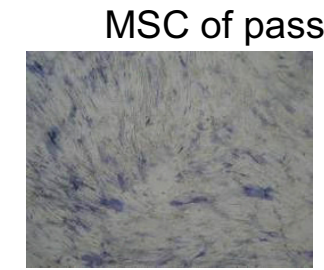

(A) Control, day 21

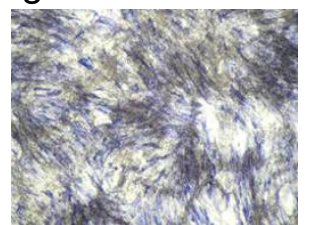

(B) Induced, day 21

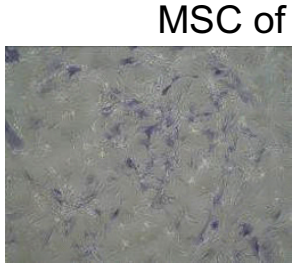

(A) Control, day 21

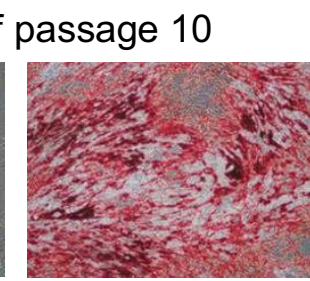

(B) Induced, day 21

\section{Morphological alterations during osteogenesis}

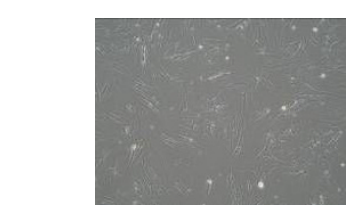

MSC on day of induction

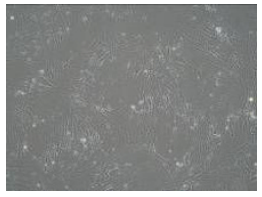

MSC on day 4 after induction

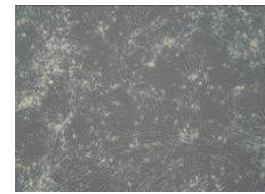

MSC on day 7 after induction

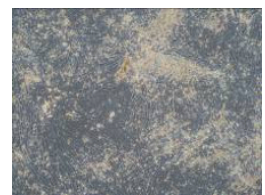

MSC on day 14 after induction

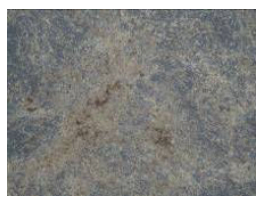

MSC on day 21 after induction

\section{Evaluation of adipogenic differentiation ability after 26 cell doublings by Oil Red $O$ staining}

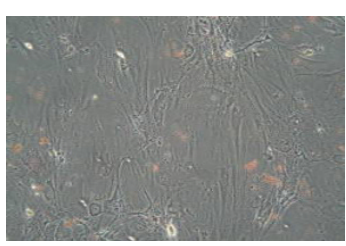

(A) Control, day 21

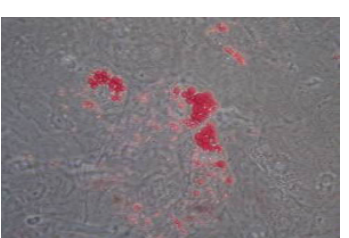

(B) Induced, day 21

\section{Figure I}

Upper panel: Osteogenic differentiation of MSC after passage 2 (A, B) and passage I0 (C, D). Alizarin Red S staining and Alkaline phosphatase assay were performed after 21 days of osteogenic induction ( 121 ). I $00 \times$ magnification. Middle Panel: Morphological alterations during osteogenesis determined by microscopy on the day of induction (d0), day 4, 7, I4 and 21 after induction. All pictures are shown in 100x magnification. Lower Panel: Adipogenic differentiation of MSC in passage 10 characterized by Oil red $\mathrm{O}$ staining; (A) MSC not induced, undifferentiated; (B) MSC 2I days after induction with adipogenic medium I00x magnification.

global mean and dye swap normalization, and replicate handling, 838 genes could be detected as differentially expressed with at least 2-fold change, between cells from passage 2 with cells from passage 5, and 345 genes, when comparing passage 5 cells with passage 10 cells [see Additional file 6]. A modified version of the regularized $t$-test
[22] with the complete data set was performed to identify significantly differentially expressed genes in ten examined donors (Nr. 1-10, passage 2 vs. passage 5) and five examined donors (Nr. 6-10, passage 5 vs. passage 10). The results showed that only 9 genes were significantly differentially expressed $(\mathrm{p}<0.05)$ during 8 cell doublings 
when comparing cells from passage 2 versus cells from passage 5 (Table 1). Significantly differentially expressed genes represent proteins with diverse functions: extracellular matrix proteins (Col11A1, tenascin $\mathrm{xb})$, proteins involved in bone, fat and epithelial cell metabolism (osteoprotegerin, b219ob receptor, FGF- 7), pain perception and stress response (proenkephalin), growth-promoting activity (IGF-2), and signaling and cell survival mechanisms (semaphorin 3c). The hypothetical protein XP_016240 is annotated as similar to keratinocyte growth factor-like protein, and the hypothetical protein dkfz434b044 is defined as a cysteine-rich secretory protein containing LCCL domain 2. The expression data from the above mentioned genes could be confirmed by independent real-time RT-PCR [see Additional file 7].

In sum, these results show that long-term expansion of MSC did not alter their differentiation potential, surface marker profiles, and expression profiles.

\section{Expression profiling of MSC during osteogenic differentiation reveals distinct phases of osteogenic development}

Osteogenic differentiation

Human MSC from three different donors (Nr. 9-11) were cultured until their fourth passage and were induced to osteogenic differentiation at a confluence of $70-80 \%$. The osteogenic differentiation was observed during the whole period by microscopy and was terminated on day 21 after induction. First signs for calcification appeared as black regions within the cell monolayer after around seven days. The maximum of calcified extracellular matrix was observed after 21 days of treatment (Figure 1). The osteoblast phenotype was confirmed by Alkaline Phosphatase assay and Alizarin Red S staining (data not shown).

\section{Expression of osteoblast specific marker genes}

We performed Real-time RT-PCR assays to detect the expression levels of osteoblast specific marker genes MSX2 (homeobox gene MSX2), VDR (vitamin D receptor), COL1A1 (collagen 1A1), ALPL (alkaline phosphatase), SPARC (osteonectin), SPP1 (osteopontin) and BGLAP (osteocalcin) to prove the osteoblast phenotype. The log2 transformed results are shown in the supplementary material [see Additional file 8].

The data obtained by Real-time RT-PCR showed the expected expression profiles of the osteoblast phenotype. ALPL showed the expected expression level progression. Its expression was increased starting with day four of the differentiation period and decreased after day 14 until day 21 during the mineralization phase. The homeobox gene MSX2, which is implicated in osteoprogenitor cell function [23] and an up-stream regulator of RUNX2, which was described to be important for the osteogenic differen- tiation [24], were up-regulated during the whole period of differentiation. COL1A1 is known to be an early marker of osteoprogenitor cells [25]. Its maximum of expression was reached on day 21 . Also SPARC showed a nearly constant, up-regulated expression level with its maximum on day 21 of differentiation. SPP1 is an extracellular matrix protein, known to peak twice in its expression [26]: around day 4, during proliferation, and between days 1421 , during mineralization. BGLAP was described as a late marker of developing osteoblasts appearing with matrix mineralization [27] and was maximally expressed on day 21. Interestingly, BGLAP was already significantly up-regulated on day four, whereas the mineralization could not be observed before day seven.

Large-scale gene expression profiling of MSC during osteogenesis The RNA was harvested at four time points during the differentiation period and hybridized on human oligonucleotide microarrays. As reference, RNA harvested from MSC one day before the osteogenic induction was used (ArrayExpress, accession numbers A-MARS-2 and EMARS-3). After LOWESS-subgrid normalization and filtering missing values 1108 genes were selected with twofold up- or downregulated expression in at least one time point [see Additional file 9].

\section{Correspondence between co-expressed genes and phenotypic changes}

Differentially expressed genes were clustered according to their expression profiles using the $k$-means clustering method [28] [see Additional file 10]. The cluster analysis was performed with at maximum 50 iterations and using 12 different clusters, each containing between 58 and 167 genes (Figure 2). The number of clusters was estimated by FOM analyses [see Additional file 11]. Additionally, hierarchical clustering was performed and the results were comparable to $k$-means clustering [see Additional file 12].

By analyzing the genes of the different clusters and their expression profiles, we were able to reconstruct three main phases of osteogenic development (Figure 3): proliferation, matrix maturation, and mineralization. Additionally, novel candidate genes could be found which are not known to play a role during osteogenic differentiation: ID4 (inhibitor of DNA-binding), CRYAB (crystalline- $\alpha \mathrm{B}$ ) and SORT1 (sortillin1). The expression of these genes was subsequently confirmed by quantitative RT-PCR [see Additional file 13].

For gene ontology (GO) analysis we categorized ESTs with available RefSeq annotation (506 RefSeq annotations out of 1108 differentially expressed genes) according to GO terms for biological process (Figure 4), cellular component, and molecular function [see Additional file 14]. In detail, cluster 3 and 11 represented proliferation phase 
Table I: Differentially expressed genes of MSC after high grade expansion.

\begin{tabular}{|c|c|c|c|}
\hline Passage 2 vs passage 5 Acc.No & Gene name & log2 ratio & Fold-change \\
\hline XM_016240 & $\begin{array}{l}\text { hypothetical protein XP_016240; loc } 87477 / / \text { Homo sapiens similar to } \\
\text { keratinocyte growth factor-like protein, group II - human }(\mathrm{LOCI} 58 \mid 16)\end{array}$ & 0.92 & 1.89 \\
\hline NM_0062II_I & proenkephalin; penk & 1.58 & 2.99 \\
\hline NM_001854_I & collagen, type xi, alpha I; coll la I & 1.27 & 2.41 \\
\hline BC010956_I & similar to fibroblast growth factor 7 (keratinocyte growth factor) & 1.03 & 2.04 \\
\hline NM_000612_I & Insulin-like growth factor 2 (somatomedin A); igf2 & 1.59 & 3.01 \\
\hline NM_031476_I & hypothetical protein dkfzp434b044; dkfzp434b044 & 1.34 & 2.53 \\
\hline U52914_I & b219ob receptor isoform hub219.3 precursor & 1.13 & 2.19 \\
\hline NM_006379_I & $\begin{array}{l}\text { sema domain, immunoglobulin domain (ig), short basic domain, secreted, } \\
\text { (semaphorin) 3c; sema3c }\end{array}$ & -0.69 & 0.62 \\
\hline NM_002546_I & osteoprotegerin; tnfrsfl lb & -1.03 & 0.49 \\
\hline \multicolumn{4}{|l|}{ Passage 5 vs passage 10 Acc. No } \\
\hline NM_019105_I & tenascin $x b$ & 0.85 & 1.80 \\
\hline
\end{tabular}

List of differentially expressed genes after statistical analysis by modified version of the regularized t-test [64] $(p<0.05)$ for ten donors (passage 2 vs. passage 5 ) and five donors (passage 5 vs. passage 10).

describing genes, which were involved in signal transduction, regulation of cell cycle, metabolism and regulation of transcription. Cluster 8 and 9 illustrated genes which were up-or down regulated during the whole period of differentiation. They describe the phase matrix maturation and are involved in development, cell differentiation, metabolism, regulation of DNA-dependent transcription. The phase of mineralization is evident in cluster 7 and 12 , which include genes involved in signal transduction, transport, metabolism, and development.

The GO analysis showed that genes found in cluster 2 and 6 were also involved in cell adhesion, signal transduction, cell cycle, and regulation of transcription, similar to cluster 3 and 11. Cluster 10 described genes of development and metabolism among the rest. Cluster 1 and 5 combined genes of cell adhesion, transport, cell proliferation and regulation of transcription. Cluster 4 represented genes associated with transport and regulation of transcription.

In summary, GO annotation showed that nearly in each cluster genes of cell adhesion, signal transduction, transport, and regulation of transcription were present, illustrating the complex regulation of different events during osteogenesis.

Pathway analysis of the expression data set

The data set of 1108 genes with significant up or down regulation $(+/-2$ fold, $\mathrm{p} \leq 0.05)$ was mapped with the Pathway Explorer on pathways derived from the Biocarta and KEGG database [29,30]. In total 276 out of 1108 genes could be mapped with their available RefSeq numbers $(24.9 \%)$. Only pathways where at least $10 \%$ and more than five mapped genes could be found were selected for further examination. Following these criteria the TGF- $\beta$ signaling pathway (12 mapped genes out of
$116,10.38 \%$, see Figure 5) was ranked first, which summarized the different Smad pathways regulated by the members of the TGF- $\beta$ family: BMP, TGF- $\beta$ and inhibin.

Cell growth and proliferation is controlled by the members of the TGF- $\beta$ superfamily which includes structurally related proteins like TGF- $\beta$, activins, and bone morphogenetic proteins (BMPs) [31-34]. In the here presented TGF$\beta$ signaling pathway BMP2 and BMP6, MADH1 and MADH9 (corresponding to SMAD1 and SMAD9) were up-regulated and the inhibitor of DNA binding ID4 was down-regulated (Figure 5). BMP2 and BMP6 are able to bind to BMPR-type I and II, whereas BMP6 is able to bind to ActRIIA [35,36]. Due to the binding of these two molecules to the heterodimeric receptor complex the SMAD signaling pathway is activated. Our data illustrated further, that the inhibitor of DNA binding, ID4 was down regulated and the osteogenic differentiation could be induced. In parallel, TGF- $\beta 2$, inhibin A and B were downregulated during the differentiation period, whereby the following events were suppressed. Hence, under these experimental conditions the Smad-signaling pathway activated by BMP2 was responsible for the osteogenic development. In contrast, the activation of the Smad pathway by TGF- $\beta$ and inhibin was suppressed.

\section{In vivo relevance of human MSC as in vitro differentiation model}

The in vitro differentiation of MSC into osteoblasts is often used model to examine the regulation mechanisms during osteoblast development. To evaluate the in vivo relevance of this model, we compared the RNA obtained at the diverse time points during osteogenic differentiation with RNA isolated from primary cultures of normal nonmineralized human osteoblasts derived from hipbone using our microarrays (ArrayExpress, accession numbers A-MARS-2, and E-MARS-4) [see Additional files 15, 16, 

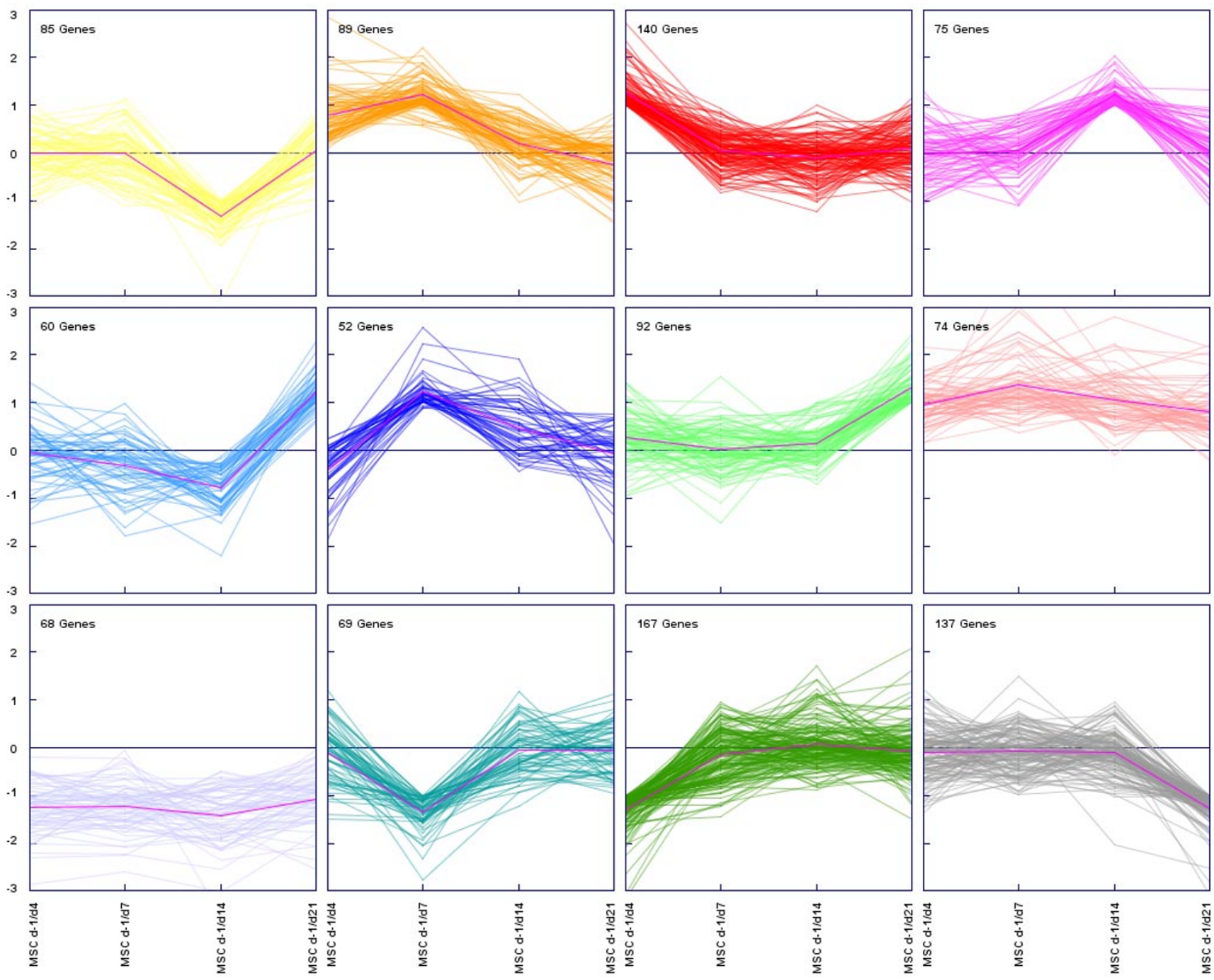

Figure 2

Expression view of all clusters calculated by k-means clustering. K-means clustering was performed for I I08 selected genes/ ESTs shown to be more than two fold up or down regulated in at least one time point during osteogenic differentiation. Genes were grouped in 12 clusters with distinct expression profiles. Relative expression levels (log 2 ratios) are shown for each gene at different time points and for the mean expression values (magenta line).

17]. The results showed that MSC on day seven of their differentiation were most similar to human osteoblasts [see Additional file 18]. This observation could be confirmed by the comparison of the morphology of the two cell types: Human osteoblasts isolated from hipbone represented non-mineralized osteoblasts with fibroblast-like phenotype, morphologically similar to induced MSC on day seven after induction.

\section{Discussion}

In this study we could show for the first time that MSC maintain their undifferentiated phenotype after ex vivo long-term expansion. The results of the microarray assays showed that MSCs did not change significantly their gene expression profiles during long-term expansion since only nine out of almost 30.000 genes were differentially expressed between passage 2 and passage 5 in ten donors. In addition, no changes in the expression profiles after additional 5 passages could be observed in five of the ten donors. These surprising results can only be partially explained by the limitations of the microarray technology. Due to the lower sensitivity and uncomplete coverage of the transcriptome, some genes required for stem cell maintenance might have been missed. Additionally, individual differences between the donors and slightly different conditions during tissue extraction and sample 


\section{A) Phenotypic changes during osteogenic development}

day of osteogenic induction

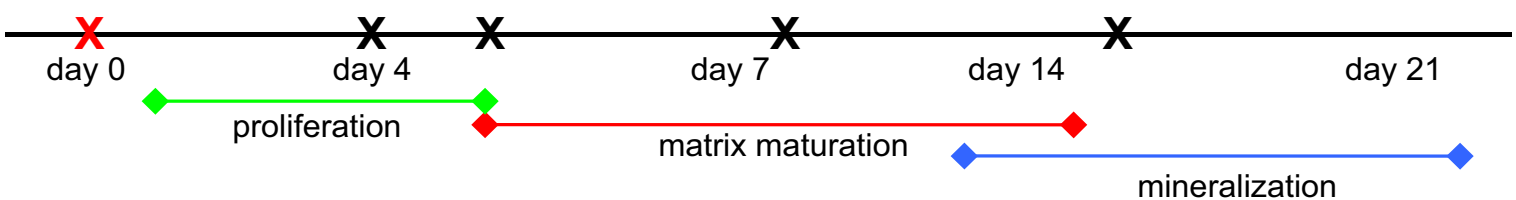

\section{B) Expression time-course of osteogenic regulator genes during distinct differentiation phases}

3)

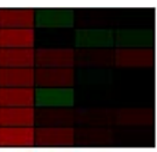

"transcription factor 1, hepatic: If-b1, hepatic nuclear factor (hnf1), albumin proximal factor; tcf1" interleukin 9: il9

cancers; mcc"

"ras homolog gene family, member b: arhb"

"adenomatous polyposis coli like: apcl

"similar to jun n-terminal kinase binding protein $1: "$

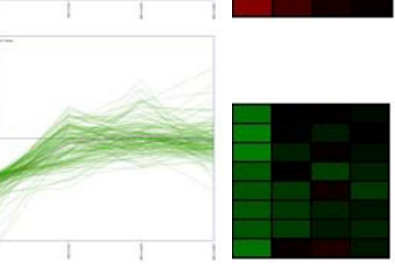

mitogen-activated protein kinase kinase kinase 2; map3k

"caspase 6 , isoform beta: casp6

cyclin-dependent kinase 8 ; cdk

activin a type ii receptor precursor; acvi2

v-jun avian sarcoma virus 17 oncogene homolog: ju

"sibit of dna binding 4, dominant negative helix-loop-helix protein; id4"

11)

"signal transducer and activator of transcription 1,91kd; stat1"

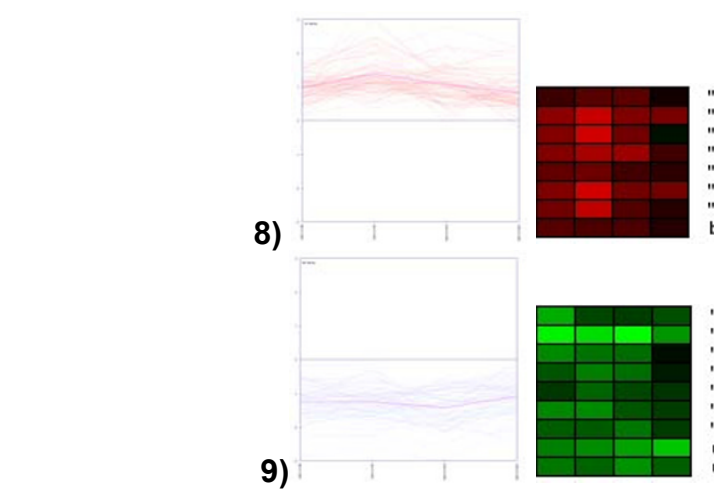

"tissue non-specific alkaline phosphatase precursor; alpl"

"bone morphogenetic protein 2 precursor; bmp2

"alpha 1 type viii collagen precursor; col8a1"

"sortilin 1: sort1"

"mad, mothers against decapentaplegic homolog 1 (drosophila); madh1"

"forkhead box m1; foxm 1

bone-type alkaline phosphatase

9)

"insulin-like growth factor binding protein 3; igfbp 3 "

"insulin-like growth factor binding protein 5 ; igfbp5"

"stromal cell-derived factor 1 ; sdf 1 "

-

"wnt1 inducible signaling pathway protein 2: wisp2"

"stromal antigen 1; stag1"

undulin 1
undulin 2
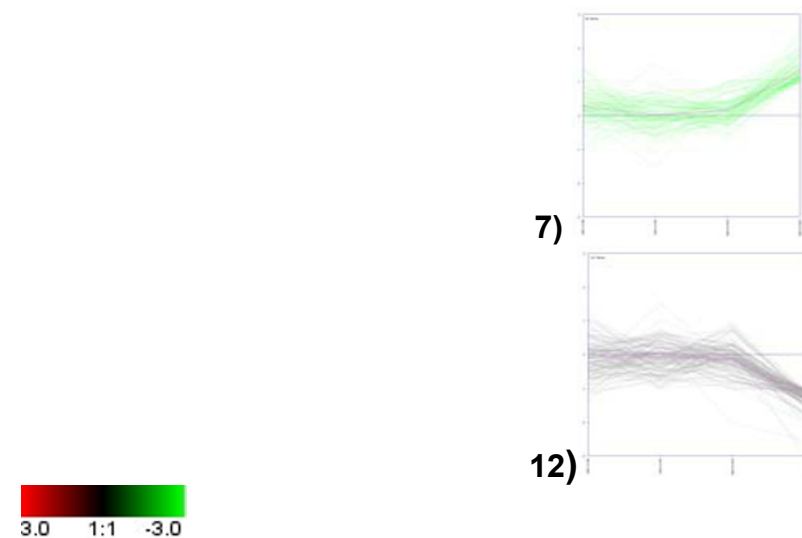

7)

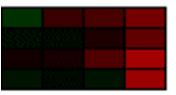

mator type a: ednra

kinase 5: map3k

alpha 1 type $i$ collagen preproprotein: col1a 1

"secreted protein, acidic, cysteine-rich; sparc"

12)

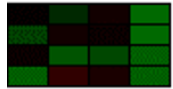

adipose most abundant gene transcript $1 ;$ apm 1

parathyroid hormone: pth

"transforming growth factor, beta 2; tgfb2"

\section{Figure 3}

Summary of osteogenic development; a) Graphical summary of the 3 phases of osteogenic development merged with the time scale; b) Chosen clusters after $k$-means clustering describing each developmental phase merged with the expression matrix of distinct key regulators. 

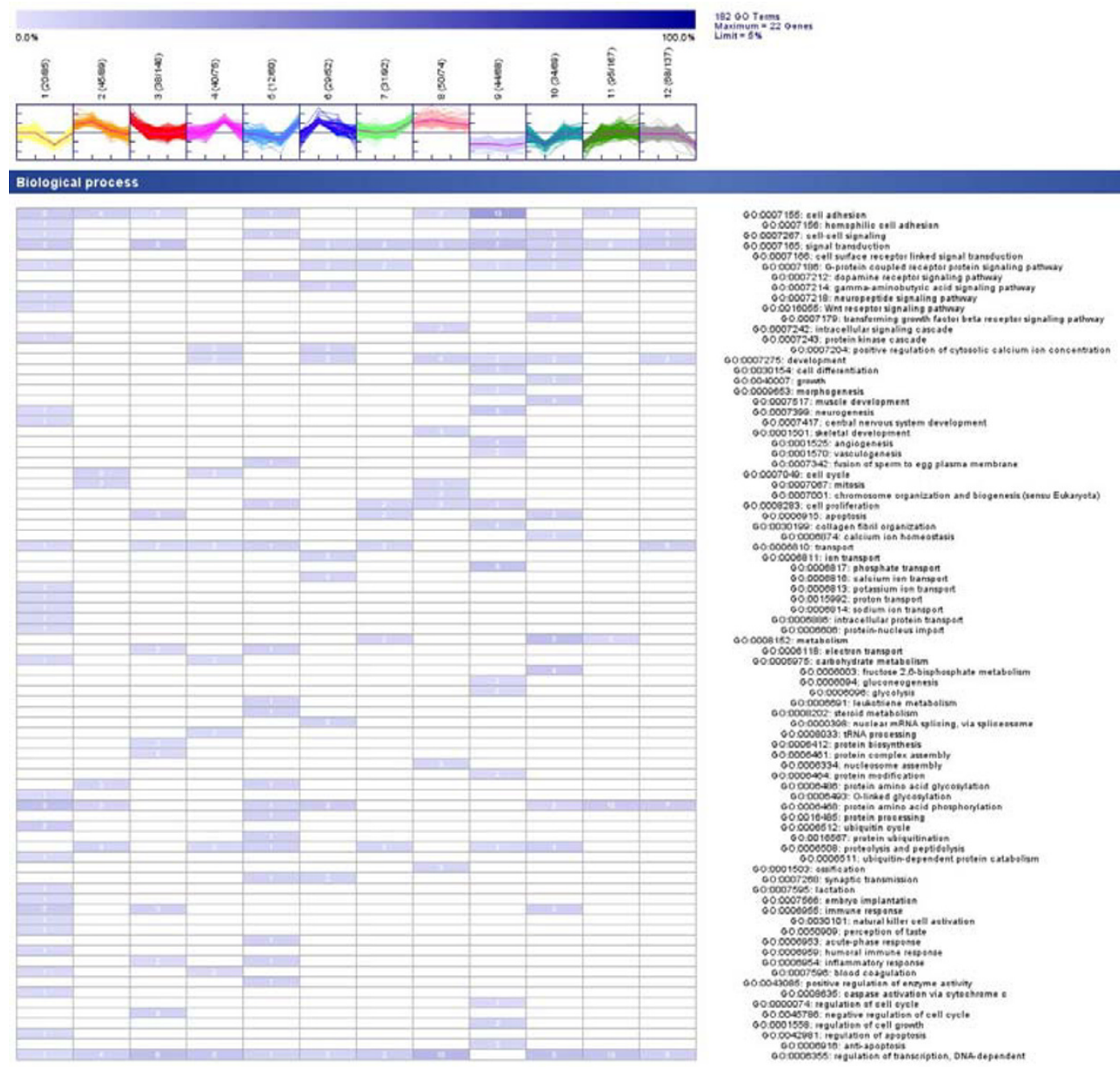

Figure 4

Distribution of gene ontology (GO) terms regarding biological processes for genes in each cluster. The GO terms listed here are those present in at least $5 \%$ of the genes within the cluster. In brackets are the number of genes with associated GO terms and the number of genes within the cluster.

treatment could increase the number identified genes which were otherwise filtered out during averaging. However, the microarray results were supported by the analyses of the effects of extensive long-term ex vivo cultivation of MSC on their proliferation capacity, their morphology, surface marker profile, and differentiation ability. During the long cultivation time we could observe, in concordance with other groups $[37,38]$, a progressive lost of proliferation ability and a slight shift in the cell-morphology of MSC of higher passage. However, their surface marker profile determined by flow cytometry (CD44+, CD90+, CD73+, CD105+, CD166+, CD45-, CD117-, HLA DR) and by Real-time RT-PCR was not altered. Over and above, the stem cell markers like CD90 and STRO1 showed stable expression levels, which further supports our observation that MSC maintained their undifferenti- ated phenotype and remained capable of osteogenic differentiation during ex vivo expansion at all tested passages (p2-p10).

Additionally to this clinically relevant evidence, we provide novel biological insights derived from the global view of the molecular processes during osteogenic development. First, we were able to illustrate the different phases of osteogenic development in a human model. Temporal expression of cell growth and osteoblast phenotype-related genes in a rodent model were first described by Stein et al. [39]. In our study, using large-scale expression profiling of clinical samples we could associate gene clusters to the three distinct phases of the development of osteoblast phenotype: proliferation, matrix maturation and mineralization. 


\section{TGF-beta signaling pathway}

Organism: Homo Sapiens (hsa)

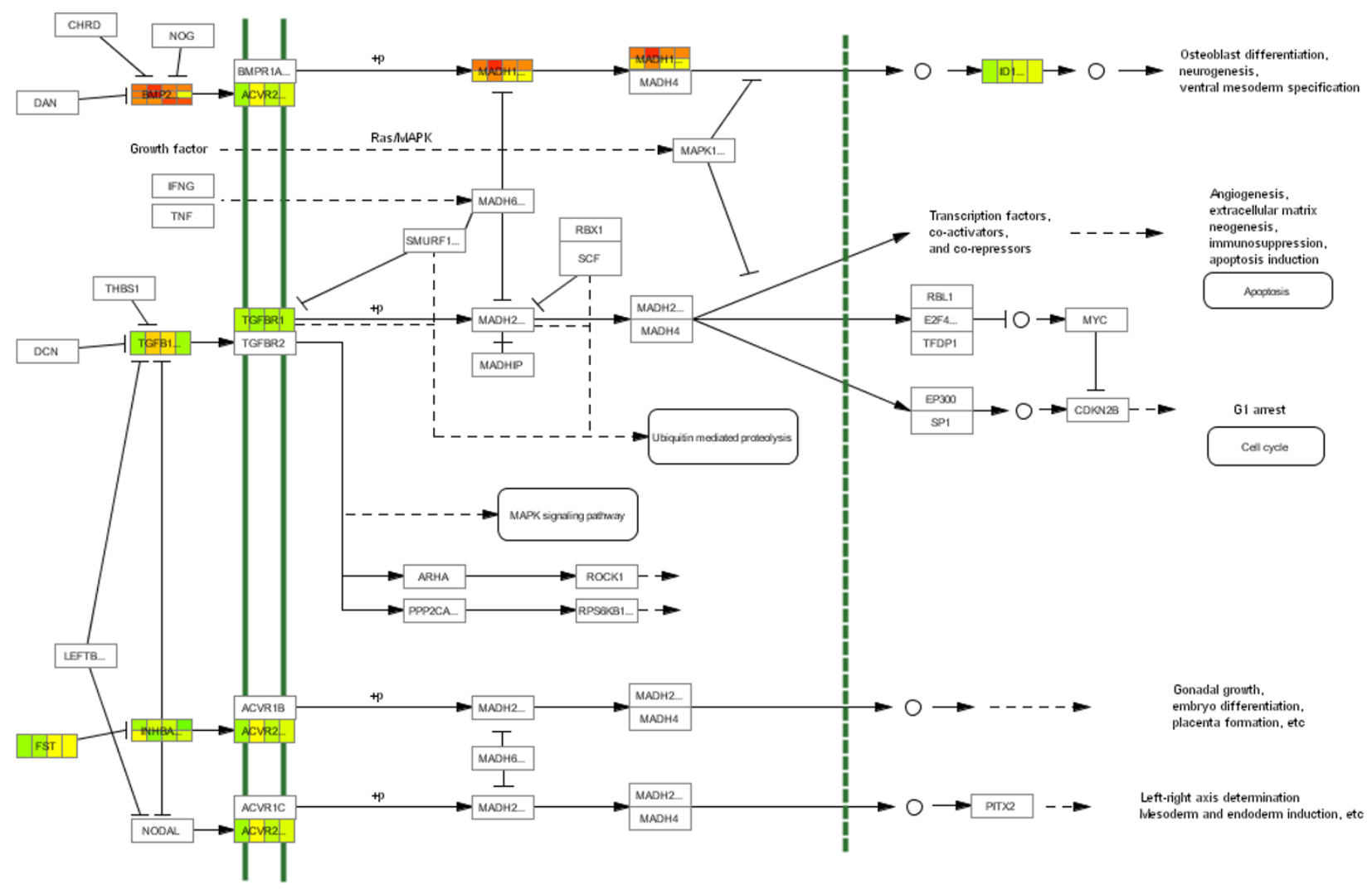

Experiments: (Homo Sapiensloroj lowesssy 1 to final data.tot)

\section{Figure 5}

Illustration of the TGF- $\beta$ signaling pathway derived from KEGG database with mapped genes according to their expression level (at least two fold up or down regulated); green = down-regulated genes, red = up-regulated genes and yellow = unregulated genes; mapped genes are at least two-fold differentially expressed.

Second, we could identify markers of late osteogenesis: ID4, CRYAB and SORT1:

a) ID4 is one of the four members of the ID (inhibitor of DNA binding) transcription factor family, which belongs to the basic-helix-loop-helix (bHLH) family. The ID members play a key role in differentiation processes and are involved in cell cycle control and cellular senescence [4043]. It has been shown that ID proteins, by heterodimerization with bHLH proteins (MyoD, E12, E47), inhibit their binding to DNA, thus acting as dominant negative regulators, and have to be down-regulated to continue the differentiation process $[44,45]$. To the best of our knowledge only ID1, ID2 and ID3 have been identified as most significantly up-regulated early targets of the osteogenic BMP2, BMP6 and BMP8 [46]. In our study we provide evidence that also ID4 exhibits a specific role during the osteogenic differentiation.

b) The second identified gene is crystallin- $\alpha B$ (CRYAB). Alpha crystallins are small heat shock proteins and composed of two gene products: alpha-A and alpha- $\mathrm{B}$, for acidic and basic. Alpha-A is preferentially restricted to the vertebrate eye lens where it maintains the transparency 
and refractive index of the lens, whereas alpha-B is widely expressed in many tissues and organs [47]. The here observed up-regulation of CRYAB suggests an involvement in osteogenic differentiation but its specific role is still unknown. This involvement is supported by Furushima et al. [48], who performed a linkage study with knowledge-based candidate genes to detect genetic determinants associated with OPLL (ossification of the posterior longitudinal ligament of the spine), a predominant myelopathy among Japanese. The candidate genes for examination were obtained by cDNA microarray analysis of gene expression profiles during osteoblastic differentiation of MSC. Among the 24 genes identified in cDNA microarray analysis which could be associated with bone metabolism, CRYAB was the only gene which showed significant evidence of linkage.

c) Further, we could show the role of sortilin 1 during osteogenic differentiation. Sortilin 1 (SORT1) represents a multi-ligand type- 1 receptor which binds a number of unrelated ligands that participate in a wide range of cellular processes. The expression of SORT1 was increasing until day seven and then slowly decreasing. Sortilin 1 , also known as neurotensin receptor-3, is a glycoprotein originally purified from human brain [49]. The expression of sortilin1 is ubiquitous; it has been observed in heart, brain, placenta, lung, skeletal, muscle, pancreas, prostate, testis, small intestine, thyroid, and spinal cord, whereas its expression in bone marrow could not be detected [50]. The function of srotilin 1 in bone metabolism is poorly understood. Maeda et al. [51] reported first differential expression during osteogenic differentiation and performed further experiments, which showed that sortilin 1 is promoting extracellular matrix maturation. Our results presented here strengthen this hypothesis, since sortilin 1 shows a similar expression progression as other well known osteogenic genes, such as ALPL or BMPs.

In summary, we have identified by expression profiling and confirmed by quantitative RT-PCR three markers of late osteogenesis. Further studies are necessary to quantify the expression of ID4, SORT-1 and CRYAB in primary human osteoblasts and other cell types and to identify the role of these genes in osteogenesis.

Third, by mapping the obtained expression data on curated biomolecular pathways, we were able to illustrate the distinct activation of the different Smad pathways induced by BMPs, TGF- $\beta$ and inhibin, which were summarized as TGF- $\beta$ pathways. The mapping of the expression data demonstrated that the fate of cell differentiation was simultaneously controlled at three different points: 1) BMP2, BMP6 and BMP8 activated the Smad-signaling pathway, consisting of the main components Smad 1, Smad 5 and Smad 8 resulting in osteoblast differentiation;
2) TGF- $\beta 2$, regulating Smad 2 and Smad 4, was down regulated and the subsequent mechanisms were suppressed; and 3 ) inhibin was, like TGF- $\beta 2$, down regulated. These findings have been confirmed by recent reports describing the diverse Smad-signaling pathways, but have never been illustrated in a general overview before this study [52-55].

Finally, the comparison of in vitro differentiated osteoblasts with in vivo developed osteoblasts on morphological and genetic level proved the usefulness of MSC as in vitro model for the investigation of the osteogenic development.

\section{Conclusion}

The here presented results demonstrate that MSC represent a cell population which can be expanded ex vivo and differentiated into osteoblasts. The genomic approach presented here represents a powerful tool to systematically and comprehensively investigate therapeutic approaches and hence, facilitate translational research on stem cells. However, it should be pointed out that new quality and safety standards have to be developed to guarantee risk free usage of ex vivo manipulated cell material for future therapeutic applications.

\section{Methods \\ Cultivation and ex vivo expansion of human bone marrow-derived MSC and normal human osteoblasts}

The mononuclear cell fractions (MNC) were derived from bone marrow from eleven different donors (Table 2), who gave consent after full information and approval by the hospital ethical committee (No. 12-091). All MNC were isolated from bone marrow aspirates at iliac crest during surgery. MNC were seeded at a density of $1 \times 10^{5}$ per $\mathrm{cm}^{2}$ and cultured for 24 hours. After these 24 hours nonadherent cells were removed by medium exchange. The adherent cells were cultured in expansion medium containing DMEM (Invitrogen), 10\% FBS (selected lot, Stem Cell Technologies), $100 \mathrm{U} / \mathrm{ml}$ penicillin, $100 \mu \mathrm{g} / \mathrm{ml}$ streptomycin and $2 \mathrm{mM}$ L-glutamine under a humidified atmosphere of $5 \% \mathrm{CO}_{2}$ at $37^{\circ} \mathrm{C}$. Medium was changed three times a week. After reaching a confluence of $75-85 \%$ the cells were detached with $0.05 \%$ trypsin $/ 1 \mathrm{mM}$ EDTA and replated at density of $4 \times 10^{3} \mathrm{cells} / \mathrm{cm}^{2}$. The cells were expanded until the end of the tenth passage (corresponding to 26 cell doublings).

The cells for the cultivation of normal human osteoblasts derived from hipbone were obtained by PromoCell (Heidelberg, Germany). The cryopreserved normal human osteoblasts were thawed and cultivated until the end of the fourth passage following the protocols and media recommended by PromoCell. 
Table 2: Clinical characteristics of the donors.

\begin{tabular}{|c|c|c|c|c|}
\hline No. & Sex & Age & Clinical diagnosis & Therapy \\
\hline 1 & $f$ & 64.1 & Arthrosis of hip joint & Total endoprothesis \\
\hline 2 & $f$ & 49.5 & Arthrosis of hip joint & Total endoprothesis \\
\hline 3 & $f$ & 56.0 & Osteoporotic fracture & Osteosynthesis \\
\hline 4 & $f$ & 79.3 & Arthrosis of hip joint & Total endoprothesis \\
\hline 5 & $\mathrm{~m}$ & 78.9 & $\begin{array}{l}\text { Avascular necrosis of } \\
\text { femoral head }\end{array}$ & Total endoprothesis \\
\hline 6 & $\mathrm{~m}$ & 46.1 & $\begin{array}{c}\text { Avascular necrosis of } \\
\text { femoral head }\end{array}$ & Total endoprothesis \\
\hline 7 & $\mathrm{~m}$ & 81.6 & Arthrosis of hip joint & Total endoprothesis \\
\hline 8 & $f$ & 72.6 & Arthrosis of knee joint & Total endoprothesis \\
\hline 9 & $\mathrm{~m}$ & 38.4 & Arthrosis of hip joint & Total endoprothesis \\
\hline 10 & $\mathrm{~m}$ & 39.8 & Arthrosis of hip joint & Total endoprothesis \\
\hline 11 & $f$ & 79.5 & Arthrosis of knee joint & Total endoprothesis \\
\hline
\end{tabular}

Sex, age, clinical diagnosis and therapy of the donors whose cells were used in this study.

\section{Colony-forming-units of fibroblasts (CFU-F) assay}

For determining the starting number of MSC in the mononuclear cell fraction CFU-F assays were performed. MNC from at least three donors were seeded in three concentrations, $2^{*} 10^{6}, 1 * 10^{6}$ and $0.5^{*} 10^{6}$ cells per T25 flasks, and incubated for 14 days in expansion medium without medium exchange under a humidified atmosphere of 5\% $\mathrm{CO}_{2}$ at $37^{\circ} \mathrm{C}$. After 14 days the cell suspension was removed, the adherent cells were fixed with methanol, dried and stained for 5 minutes with Giemsa staining solution (VWR). After washing with distilled water the colonies were counted and the human MSC frequency in the MNC fraction was calculated.

\section{Ex vivo differentiation of human bone marrow-derived MSC in osteoblasts and adipocytes}

For the induction of osteogenesis MSC were seeded at a density of $10^{4}$ cells/ $\mathrm{cm}^{2}$ in expansion medium. After 24 hours the differentiation was induced by medium exchange. The osteogenic differentiation medium was based on the expansion medium supplemented with 10 $\mathrm{nM}$ dexamethasone, $0.1 \mathrm{mM}$ ascorbic-acid-2-phosphate and $10 \mathrm{mM} \beta$-glycerophosphate. The adipogenic differentiation medium contained in addition to the expansion medium $0.1 \mu \mathrm{M}$ dexamethasone, $50 \mu \mathrm{M}$ indomethacin and $5 \mu \mathrm{g} / \mathrm{ml}$ insulin. The media were changed three times a week. Osteogenic differentiation was detected by Alkaline Phosphatase assay (Sigma) and Alizarin Red S staining of mineralized matrix, whereas adipogenic differentiation was detected by Oil Red O staining of the adipocyte specific fat vacuoles.

The Alkaline Phosphatase assay was performed with the Alkaline Phosphatase kit No. 85 purchased by Sigma following the manufacturers' instructions. For the Alizarin Red S staining a $1 \%$ Alizarin Red S in 2\% EtOH staining solution was prepared. The medium was removed; the cultures were washed twice with preheated $37^{\circ} \mathrm{C}$ PBS, fixed with $10 \%$ formaldehyde for 10 minutes, washed again with distilled water and incubated with the Alizarin Red S staining solution for 5 minutes. After incubation the staining solution was removed and the cultures were washed 5 times with distilled water to get rid of excessive color.

For the Oil Red O staining a $0.5 \%$ Oil Red O stock solution in 2-Propanol was prepared. For the staining procedure the stock solution was diluted 3:2 with distilled water, 10 minutes incubated at room temperature and filtrated by using Whatmanpaper \#1. The medium was removed; the cells were washed with PBS, fixed with $10 \%$ formalin for at minimum 30 minutes, and stained with the Oil Red $\mathrm{O}$ staining solution for one hour.

\section{Surface marker profiling by flow cytometry analysis}

For flow cytometry analysis the cells were detached with $0.05 \%$ trypsin/EDTA and washed with PBS. $1 \times 10^{5}$ cells per tube were blocked for 5 minutes with human $A B$ serum (Sigma) and stained for 15 minutes incubated in an ice bath in the dark with direct PE or FITC conjugated mouse anti-human monoclonal antibodies (Becton Dickinson) recognizing CD11b, CD34, CD38, CD44, CD45, CD73, CD90, CD117 and HLA-DR. After antibody incubation the cells were washed with PBS/sodium azide and resuspended in PBS in the needed volume for analyzing. 5 minutes before the analysis 7 -AAD $(0.25 \mu$ g per test) was applied to each sample for exclusion of dead cells. For negative control immunoglobulin isotype incubation was performed. FACS analyses were performed with FACS Calibur (Becton Dickinson).

\section{Sample preparation - RNA isolation}

Total RNA was isolated with TRIzol reagent (GibcoBRLLife Technologies) following the instructions of the manufacturer. RNA concentration was determined by photometric measurement. The RNA quality was analyzed by 
Agilent 2100 Bioanalyzer RNA assays and evaluated by calculating the ratio of the $28 \mathrm{~S}$ and $18 \mathrm{~S}$ ribosomal RNA intensity peaks.

\section{Microarray production}

Human oligonucleotide microarrays were developed using 29550 oligonucleotides derived from $30 \mathrm{~K} \mathrm{MWG}$ Human Oligo Set with 50 bp in length (provided by Prof. Reinhard Kofler, Tyrolian Cancer Research Institute), and dissolved in spotting buffer consisting of $3 \times$ SSC, $1.5 \mathrm{M}$ Betaine. Microarrays were produced by spotting the reporters (including spotting buffer as negative control and human genomic DNA as positive control) in 48 blocks onto an epoxy-coated glass slide (Nexterion) resulting in 33456 features on a single high density array. Reporter molecules were fixed to the slides by baking at $42^{\circ} \mathrm{C}$ for $8 \mathrm{~h}$ at $50 \%$ relative humidity. RefSeq IDs indicate the genes represented by the oligonucleotides [see Additional file 3].

\section{Microarray hybridization procedure}

The used labeling and hybridization procedures were based on those developed at The Institute for Genomic Research (TIGR) and modified at the Institute for Genomics and Bioinformatics [see Additional file 4 and 5]. All hybridizations were repeated with reversed dye assignment (dye-swap). After hybridization slides were scanned with GenePix 4000B microarray scanner (Axon Instruments) at $10 \mu \mathrm{m}$ resolution. Identical settings were used for scanning the corresponding dye-swapped hybridized slides. The resulting TIFF images for each of the two fluorophores were analyzed with GenePix Pro 4.1 (Axon Instruments).

\section{Bioinformatics analyses}

After image acquisition and filtering the data for low intensity, inhomogeneity and satured spots, the results files were normalized with the in-house developed software ArrayNorm [56]. After background correction the data sets were normalized by global-mean and dye-swap pairs or LOWESS-subgrid normalization. The obtained result files were used for further analyses such as cluster analysis [57], GO annotation [58] and pathway analyses [59]. Cluster analyses were performed with the Genesis software tool using $k$-means clustering function [28]. The number of clusters was varied from $\mathrm{k}=1$ to $\mathrm{k}=15$ and predictive power was analyzed with the figure of merit [60]. Subsequently, k = 12 was found optimal. GO annotation was performed on differentially expressed genes. Pathway analyses were performed with the in house developed Pathway Explorer software [59] which mapped the RefSeq IDs from the results file (cut-off level for differentially expressed genes: $\log 2$ ratio $>1$ ) on public available pathways like Biocarta [61] and KEGG database [30]. All experimental parameters, images, raw and transformed data were uploaded to the microarray database MARS [62] and submitted via MAGE-ML export to a public repository (ArrayExpress, accession numbers A-MARS-2, E-MARS-3, E-MARS-4, E-MARS-5, and E-MARS-6) [63].

\section{Real-time RT PCR}

The same sources of total RNA used in the microarray experiments were used for the data validation by RT-PCR. The SuperScript ${ }^{\mathrm{TM}}$ II First Strand Synthesis System for RT PCR (Invitrogen) was used to synthesize cDNA of $5 \mu \mathrm{g}$ RNA following manufacturers' recommendations. RNA contaminating genomic DNA was removed by treatment with DNAse I amplification grade (Invitrogen). The SuperScript ${ }^{\mathrm{TM}}$ II product was diluted 1:25 and directly used for the RT-PCR.

The RT-PCR assays were performed using the Eurogentec $\mathrm{qPCR}^{\mathrm{TM}}$ Mastermix Plus for Sybr ${ }^{\mathrm{TM}}$ Green I following manufacturer's recommendations. NO-reverse transcription Controls (No-RT) and No-Template Controls (NTC) were performed for each RNA type and primer pair. Cycling conditions on the ABI Prism 7000: 2 minutes at $50^{\circ} \mathrm{C}, 10$ minutes at $95^{\circ} \mathrm{C}, 40 \times\left(15\right.$ seconds at $95^{\circ} \mathrm{C}, 1$ minute at $60^{\circ} \mathrm{C}$ ) and the dissociation protocol at $60^{\circ} \mathrm{C}$ was added. For each sample RNA two cDNAs were prepared but in independent reverse transcription reactions. Each gene was tested with both cDNAs and the cDNAs were also tested in duplicate on one plate. Hence, four RT-PCR reactions were performed for the examination of one single gene. Further, the sample cDNA and the corresponding reference cDNA were tested on one plate, so that the data can be compared directly.

For normalization of the data the average of the expression level of four house-keeping genes, GAPDH, HPRT, beta-actin and beta-tubulin, was used.

\section{Authors' contributions}

BK performed the experiments and analyzed the data. FSC was responsible for the microarray data normalization and statistical analysis. GF isolated the bone marrow aspirates. RW was responsible for the clinical studies. $\mathrm{AJ}$ and KHP supported the design of the experiments and the interpretation of the results. MS, CP, and AP developed and produced the microarrays. ZT was responsible for the overall conception and project coordination. All authors gave final approval of the version to be published.

\section{Additional files}

There are 18 additional files provided with the online version of this manuscript comprising raw data and results of the analyses. The data files are available on our web site http://genome.tugraz.at/MSC. 


\section{Additional material}

\section{Additional File 1}

FACS analysis. Surface profiles in different passages.

Click here for file

[http://www.biomedcentral.com/content/supplementary/1471-

2164-8-70-S1.pdf]

\section{Additional File 2}

Expression of stem cell specific marker genes evaluated by Realtime RTPCR. Expression of stem cell specific marker genes evaluated by Realtime RT-PCR.

Click here for file

[http://www.biomedcentral.com/content/supplementary/1471-

2164-8-70-S2.pdf]

\section{Additional File 3}

Array Design. Information on the spotted oligos.

Click here for file

[http://www.biomedcentral.com/content/supplementary/1471-

2164-8-70-S3.xls]

\section{Additional File 4}

SOP AMINOALLYL LABELING OF RNA FOR HUMAN OLIGO

CHIPS. Standard Operating Procedure for AMINOALLYL LABELING OF RNA FOR HUMAN OLIGO CHIPS.

Click here for file

[http://www.biomedcentral.com/content/supplementary/1471-

2164-8-70-S4.pdf]

\section{Additional File 5}

SOP HUMAN OLIGO CHIP PROBE HYBRIDIZATION. Standard

Operating Procedure for microarray hybridization.

Click here for file

[http://www.biomedcentral.com/content/supplementary/1471-

2164-8-70-S5.pdf]

\section{Additional File 6}

Differentially expressed ESTs. Differentially expressed ESTs (>2-fold-

change) when comparing $p 2 / p 5$ and $p 5 / p 10$ for following moderated $t$ test

Click here for file

[http://www.biomedcentral.com/content/supplementary/14712164-8-70-S6.xls]

\section{Additional File 7}

Validation of microarray data by Realtime RT-PCR. Gene expression analysis of long-term cultivated MSC.

Click here for file

[http://www.biomedcentral.com/content/supplementary/1471-

2164-8-70-S7.pdf]

\section{Additional File 8}

Gene expression of osteoblast specific genes determined by Real-time RTPCR. Gene expression of osteoblast specific genes determined by Real-time RT-PCR to prove the osteogenic phenotype.

Click here for file

[http://www.biomedcentral.com/content/supplementary/14712164-8-70-S8.pdf]

\section{Additional File 9}

Selected ESTs for microarray analysis. 1108 selected ESTs for microarray analysis.

Click here for file

[http://www.biomedcentral.com/content/supplementary/1471-

2164-8-70-S9.xls]

\section{Additional File 10}

$k$-means clustering. $k$-means clustering of 1108 selected ESTs.

Click here for file

[http://www.biomedcentral.com/content/supplementary/1471-

2164-8-70-S10.pdf]

\section{Additional File 11}

Figure of merit analysis. Figure of merit analysis for validation of the $k$ value.

Click here for file

[http://www.biomedcentral.com/content/supplementary/1471-

2164-8-70-S11.pdf]

\section{Additional File 12}

Hierarchical clustering. Hierarchical clustering of 1108 selected ESTs. Click here for file

[http://www.biomedcentral.com/content/supplementary/1471-

2164-8-70-S12.png]

\section{Additional File 13}

Validation of microarray data using real-time RT-PCR. Gene expression analysis of MSC during osteogenesis.

Click here for file

[http://www.biomedcentral.com/content/supplementary/1471-

2164-8-70-S13.pdf]

\section{Additional File 14}

Functional annotation. Distribution of gene ontology (GO) terms in each cluster.

Click here for file

[http://www.biomedcentral.com/content/supplementary/1471-

2164-8-70-S14.png]

\section{Additional File 15}

Expression matrix. Expression matrix of differentially expressed ESTs (>2foldchange).

Click here for file

[http://www.biomedcentral.com/content/supplementary/1471-

2164-8-70-S15.png]

\section{Additional File 16}

Selected ESTs for microarray analysis. 659 selected ESTs for microarray analysis.

Click here for file

[http://www.biomedcentral.com/content/supplementary/1471-

2164-8-70-S16.xls]

\section{Additional File 17}

Validation of microarray data by real-time RT-PCR. Real-time RT-PCR data.

Click here for file

[http://www.biomedcentral.com/content/supplementary/14712164-8-70-S17.pdf] 


\section{Additional File 18}

Evaluation of human MSC as in vitro differentiation model. Comparison of human osteoblasts with in vitro differentiated hMSC.

Click here for file

[http://www.biomedcentral.com/content/supplementary/14712164-8-70-S18.pdf]

\section{Acknowledgements}

We thank Hubert Hackl for assistance with the additional data files, Bernhard Mlecnik for the pathway analyses, and Robert Molidor for the microarray database support. This work was supported by the Christian-Doppler Laboratory for Genomics and Bioinformatics, and the GEN-AU projects Bioinformatics Integration Network (BIN) and Genomics of Lipid-Associated Disorders (GOLD).

\section{References}

I. Haynesworth SE, Goshima J, Goldberg VM, Caplan Al: Characterization of cells with osteogenic potential from human marrow. Bone 1992, 13:81-88.

2. Bruder SP, Jaiswal N, Haynesworth SE: Growth kinetics, selfrenewal, and the osteogenic potential of purified human mesenchymal stem cells during extensive subcultivation and following cryopreservation. J Cell Biochem 1997, 64:278-294.

3. Pittenger MF, Martin BJ: Mesenchymal stem cells and their potential as cardiac therapeutics. Circ Res 2004, 95:9-20.

4. Xu W, Zhang X, Qian H, Zhu W, Sun X, Hu J, Zhou H, Chen Y: Mesenchymal stem cells from adult human bone marrow differentiate into a cardiomyocyte phenotype in vitro. Exp Biol Med (Maywood) 2004, 229:623-631.

5. Hofstetter CP, Schwarz EJ, Hess D, Widenfalk J, El M, Prockop DJ, Olson L: Marrow stromal cells form guiding strands in the injured spinal cord and promote recovery. Proc Natl Acad Sci U S A 2002, 99:2199-2204.

6. Sanchez-Ramos J, Song S, Cardozo-Pelaez F, Hazzi C, Stedeford T, Willing A, Freeman TB, Saporta S, Janssen W, Patel N, Cooper DR, Sanberg PR: Adult bone marrow stromal cells differentiate into neural cells in vitro. Exp Neurol 2000, 164:247-256.

7. Hayflick L: Antecedents of cell aging research. Exp Gerontol 1989, 24:355-365.

8. Shake JG, Gruber PJ, Baumgartner WA, Senechal G, Meyers J, Redmond JM, Pittenger MF, Martin BJ: Mesenchymal stem cell implantation in a swine myocardial infarct model: engraftment and functional effects. Ann Thorac Surg 2002, 73: I919-1925.

9. Bruder SP, Kraus KH, Goldberg VM, Kadiyala S: The effect of implants loaded with autologous mesenchymal stem cells on the healing of canine segmental bone defects. J Bone Joint Surg Am 1998, 80:985-996.

10. Kon E, Muraglia A, Corsi A, Bianco P, Marcacci M, Martin I, Boyde A, Ruspantini I, Chistolini P, Rocca M, Giardino R, Cancedda R, Quarto $\mathrm{R}$ : Autologous bone marrow stromal cells loaded onto porous hydroxyapatite ceramic accelerate bone repair in critical-size defects of sheep long bones. I Biomed Mater Res 2000, 49:328-337.

II. Wakitani S, Goto T, Pineda SJ, Young RG, Mansour JM, Caplan AI, Goldberg VM: Mesenchymal cell-based repair of large, fullthickness defects of articular cartilage. J Bone Joint Surg Am 1994, 76:579-592.

12. Bruder SP, Jaiswal N, Ricalton NS, Mosca JD, Kraus KH, Kadiyala S: Mesenchymal stem cells in osteobiology and applied bone regeneration. Clin Orthop Relat Res 1998:S247-S256.

13. Johnstone B, Hering TM, Caplan Al, Goldberg VM, Yoo JU: In vitro chondrogenesis of bone marrow-derived mesenchymal progenitor cells. Exp Cell Res 1998, 238:265-272.

14. Woodbury D, Schwarz EJ, Prockop DJ, Black IB: Adult rat and human bone marrow stromal cells differentiate into neurons. J Neurosci Res 2000, 6 I:364-370.

15. Terada N, Hamazaki T, Oka M, Hoki M, Mastalerz DM, Nakano Y, Meyer EM, Morel L, Petersen BE, Scott EW: Bone marrow cells adopt the phenotype of other cells by spontaneous cell fusion. Nature 2002, 4 I 6:542-545.

16. Dezawa M, Takahashi I, Esaki M, Takano M, Sawada H: Sciatic nerve regeneration in rats induced by transplantation of in vitro differentiated bone-marrow stromal cells. Eur J Neurosci 200I, 14:177|-1776.

17. Horwitz EM, Gordon PL, Koo WK, Marx JC, Neel MD, McNall RY, Muul L, Hofmann T: Isolated allogeneic bone marrow-derived mesenchymal cells engraft and stimulate growth in children with osteogenesis imperfecta: Implications for cell therapy of bone. Proc Natl Acad Sci U S A 2002, 99:8932-8937.

18. Koc ON, Gerson SL, Cooper BW, Dyhouse SM, Haynesworth SE Caplan Al, Lazarus HM: Rapid hematopoietic recovery after coinfusion of autologous-blood stem cells and cultureexpanded marrow mesenchymal stem cells in advanced breast cancer patients receiving high-dose chemotherapy. J Clin Oncol 2000, 18:307-316.

19. Quarto R, Mastrogiacomo M, Cancedda R, Kutepov SM, Mukhachev V, Lavroukov A, Kon E, Marcacci M: Repair of large bone defects with the use of autologous bone marrow stromal cells. N Engl J Med 200I, 344:385-386.

20. Petite $H$, Viateau V, Bensaid W, Meunier A, de Pollak C, Bourguignon M, Oudina K, Sedel L, Guillemin G: Tissue-engineered bone regeneration. Nat Biotechnol 2000, 18:959-963.

21. Lazarus HM, Haynesworth SE, Gerson SL, Rosenthal NS, Caplan Al: Ex vivo expansion and subsequent infusion of human bone marrow-derived stromal progenitor cells (mesenchymal progenitor cells): implications for therapeutic use. Bone Marrow Transplant 1995, 16:557-564.

22. Baldi P, Long AD: A Bayesian framework for the analysis of microarray expression data: regularized $t$-test and statistical inferences of gene changes. Bioinformatics 200I, I 7:509-5I9.

23. Cheng SL, Shao JS, Charlton-Kachigian N, Loewy AP, Towler DA: MSX 2 promotes osteogenesis and suppresses adipogenic differentiation of multipotent mesenchymal progenitors. J Biol Chem 2003, 278:45969-45977.

24. Satokata I, Ma L, Ohshima H, Bei M, Woo I, Nishizawa K, Maeda T, Takano Y, Uchiyama M, Heaney S, Peters H, Tang ZQ, Maxson R, Maas R: Msx2 deficiency in mice causes pleiotropic defects in bone growth and ectodermal organ formation. Nature Genetics 2000, 24:391-395.

25. Jikko A, Harris SE, Chen D, Mendrick DL, Damsky CH: Collagen integrin receptors regulate early osteoblast differentiation induced by BMP-2. Journal of Bone and Mineral Research 1999 , 1 4:1075-1083.

26. J.E. A: Regulation of osteoblast formation and function. Rev Endocr Metab Disord 2001, 2:81-94.

27. Aubin JE: Bone stem cells. Journal of Cellular Biochemistry 1998:73-82.

28. Hartigan JA: Clustering. Annu Rev Biophys Bioeng 1973, 2:8I-I0I.

29. Biocarta pathway database 2005 [http://www.biocarta.com/ genes/index.asp].

30. Kanehisa M, Goto S, Kawashima S, Nakaya A: The KEGG databases at GenomeNet. Nucleic Acids Res 2002, 30:42-46.

31. Massague J: TGF-beta signal transduction. Annu Rev Biochem 1998, 67:753-79|.

32. Zwijsen A, Verschueren K, Huylebroeck D: New intracellular components of bone morphogenetic protein/Smad signaling cascades. FEBS Lett 2003, 546:133-139.

33. Wan M, Cao X: BMP signaling in skeletal development. Biochem Biophys Res Commun 2005, 328:65I-657.

34. Ducy P, Karsenty G: The family of bone morphogenetic proteins. Kidney Int 2000, 57:2207-2214.

35. Banfi A, Muraglia A, Dozin B, Mastrogiacomo M, Cancedda R, Quarto $\mathrm{R}$ : Proliferation kinetics and differentiation potential of ex vivo expanded human bone marrow stromal cells: Implications for their use in cell therapy. Exp Hematol 2000 , 28:707-7I5.

36. Bruder SP, Kurth AA, Shea M, Hayes WC, Jaiswal N, Kadiyala S: Bone regeneration by implantation of purified, culture-expanded human mesenchymal stem cells. J Orthop Res 1998, 16:155-162.

37. Stein GS, Lian JB: Molecular mechanisms mediating proliferation/differentiation interrelationships during progressive development of the osteoblast phenotype. Endocr Rev 1993, 14:424-442. 
38. Kreider BL, Benezra R, Rovera G, Kadesch T: Inhibition of myeloid differentiation by the helix-loop-helix protein Id. Science 1992, 255: $1700-1702$.

39. Zebedee Z, Hara E: Id proteins in cell cycle control and cellular senescence. Oncogene 200I, 20:83I7-8325.

40. Ruzinova MB, Benezra R: Id proteins in development, cell cycle and cancer. Trends Cell Biol 2003, I3:410-418.

4I. Norton JD: ID helix-loop-helix proteins in cell growth, differentiation and tumorigenesis. J Cell Sci 2000, II3 ( Pt 22):3897-3905.

42. Benezra R, Davis RL, Lockshon D, Turner DL, Weintraub H: The protein Id: a negative regulator of helix-loop-helix DNA binding proteins. Cell 1990, $61: 49-59$.

43. Pagliuca A, Cannada-Bartoli $P$, Lania L: A role for $\mathrm{Sp}$ and helixloop-helix transcription factors in the regulation of the human Id4 gene promoter activity. I Biol Chem 1998, 273:7668-7674.

44. Peng Y, Kang Q, Luo Q, Jiang W, Si W, Liu BA, Luu HH, Park JK, Li $X$, Luo J, Montag AG, Haydon RC, He TC: Inhibitor of DNA binding/differentiation helix-loop-helix proteins mediate bone morphogenetic protein-induced osteoblast differentiation of mesenchymal stem cells. J Biol Chem 2004, 279:3294 I-32949.

45. Derham BK, Harding Jl: Alpha-crystallin as a molecular chaperone. Prog Retin Eye Res 1999, 18:463-509.

46. Furushima K, Shimo-Onoda K, Maeda S, Nobukuni T, Ikari K, Koga H, Komiya S, Nakajima T, Harata S, Inoue I: Large-scale screening for candidate genes of ossification of the posterior longitudinal ligament of the spine. J Bone Miner Res 2002, I 7:128-137.

47. Petersen CM, Nielsen MS, Nykjaer A, Jacobsen L, Tommerup N, Rasmussen HH, Roigaard H, Gliemann J, Madsen P, Moestrup SK: Molecular identification of a novel candidate sorting receptor purified from human brain by receptor-associated protein affinity chromatography. J Biol Chem 1997, 272:3599-3605.

48. Maeda S, Nobukuni T, Shimo-Onoda K, Hayashi K, Yone K, Komiya $\mathrm{S}$, Inoue I: Sortilin is upregulated during osteoblastic differentiation of mesenchymal stem cells and promotes extracellular matrix mineralization. I Cell Physiol 2002, I 93:73-79.

49. Nohe A, Hassel S, Ehrlich M, Neubauer F, Sebald W, Henis YI, Knaus $P$ : The mode of bone morphogenetic protein (BMP) receptor oligomerization determines different BMP-2 signaling pathways. J Biol Chem 2002, 277:5330-5338.

50. Afzal F, Pratap J, Ito K, Ito Y, Stein JL, van Wijnen AJ, Stein GS, Lian $\mathrm{JB}$, Javed $\mathrm{A}$ : Smad function and intranuclear targeting share a Runx2 motif required for osteogenic lineage induction and BMP2 responsive transcription. J Cell Physiol 2005, 204:63-72.

5I. ten Dijke P, Goumans MJ, Itoh F, Itoh S: Regulation of cell proliferation by Smad proteins. J Cell Physiol 2002, I9 I:I-16.

52. Pieler R, Sanchez-Cabo F, Hackl H, Thallinger GG, Trajanoski Z: ArrayNorm: comprehensive normalization and analysis of microarray data. Bioinformatics 2004, 20: 197|-1973.

53. Sturn A, Quackenbush J, Trajanoski Z: Genesis: cluster analysis of microarray data. Bioinformatics 2002, 18:207-208.

54. Harris MA, Clark J, Ireland A, Lomax J, Ashburner M, Foulger R, Eilbeck K, Lewis S, Marshall B, Mungall C, Richter J, Rubin GM, Blake JA, Bult C, Dolan M, Drabkin H, Eppig JT, Hill DP, Ni L, Ringwald M, Balakrishnan R, Cherry JM, Christie KR, Costanzo MC, Dwight SS, Engel S, Fisk DG, Hirschman JE, Hong EL, Nash RS, Sethuraman A, Theesfeld CL, Botstein D, Dolinski K, Feierbach B, Berardini T, Mundodi S, Rhee SY, Apweiler R, Barrell D, Camon E, Dimmer E, Lee V, Chisholm R, Gaudet P, Kibbe W, Kishore R, Schwarz EM, Sternberg P, Gwinn M, Hannick L, Wortman J, Berriman M, Wood V, de la CN, Tonellato P, Jaiswal P, Seigfried T, White R: The Gene Ontology (GO) database and informatics resource. Nucleic Acids Res 2004, 32:D258-D261.

55. Mlecnik B, Scheideler M, Hackl H, Hartler J, Sanchez-Cabo F, Trajanoski Z: PathwayExplorer: web service for visualizing highthroughput expression data on biological pathways. Nucleic Acids Res 2005, 33:W633-W637.

56. Yeung KY, Haynor DR, Ruzzo WL: Validating clustering for gene expression data. Bioinformatics 2001, I 7:309-3। 8.

57. Maurer M, Molidor R, Sturn A, Hartler J, Hackl H, Stocker G, Prokesch A, Scheideler M, Trajanoski Z: MARS: microarray analysis, retrieval, and storage system. BMC Bioinformatics 2005, 6:101-101.

58. Brazma A, Parkinson H, Sarkans U, Shojatalab M, Vilo J, Abeygunawardena N, Holloway E, Kapushesky M, Kemmeren P, Lara GG,
Oezcimen A, Rocca-Serra P, Sansone SA: ArrayExpress--a public repository for microarray gene expression data at the EBI. Nucleic Acids Res 2003, 3 I:68-7I.
Publish with Biomed Central and every scientist can read your work free of charge

"BioMed Central will be the most significant development for disseminating the results of biomedical research in our lifetime. "

Sir Paul Nurse, Cancer Research UK

Your research papers will be:

- available free of charge to the entire biomedical community

- peer reviewed and published immediately upon acceptance

- cited in PubMed and archived on PubMed Central

- yours - you keep the copyright 